\title{
The Effectiveness of Diamel in the Treatment of Type 2 Diabetic Patients Receiving Insulin Therapy: A Randomized, Controlled Clinical Trial
}

\author{
María Elena de la Uz Herrera ${ }^{1 \#}$, Arturo Hernández Yero $^{2}$, Reinaldo González Iglesias ${ }^{3}$, \\ Urbicio Reinoso Hernández ${ }^{4}$, Alfredo Novales Amado ${ }^{5}$, María del Carmen Herrera de la Uz ${ }^{6}$, \\ Marién García Otero 7 \\ ${ }^{1}$ Internal Medicine Service, Hospital Abel Santamaría Cuadrado, Pinar del Río, Cuba \\ ${ }^{2}$ Endocrinology Service, Instituto Nacional de Endocrinología, Havana, Cuba \\ ${ }^{3}$ Diabetic Care Centre, Hospital Abel Santamaría Cuadrado, Pinar del Río, Cuba \\ ${ }^{4}$ Internal Medicine Service, Hospital Abel Santamaría Cuadrado, Pinar del Río, Cuba \\ ${ }^{5}$ Diabetic Care Centre, Hospital Abel Santamaría Cuadrado, Pinar del Río, Cuba \\ ${ }^{6}$ Medical University, Physiology Department, Pinar del Río, Cuba \\ ${ }^{7}$ Rehabilitation Service, Hospital León Cuervo Rubio, Pinar del Río, Cuba \\ Email: ${ }^{\#}$ _elena@rincesa.pri.sld.cu
}

Received August 7, 2012; revised September 9, 2012; accepted October 11, 2012

\begin{abstract}
Aims/Introduction: Effectiveness of Diamel ${ }^{\circledR}$ on the biochemical variables: fasting blood glucose, postprandial glucose, cholesterol, triglycerides, and glycosylated haemoglobin [HbAlc] in type 2 diabetic patients receiving insulin terapy. Diamel is a natural product composed of trace elements: amino acids, vitamins, cranberry extract, and lettuce extract that have been activated by means of a magnetization process. Materials and methods: Randomized, doubleblind, comparator-controlled clinical trial. A central randomization centre used computer generated tables to allocate treatments. 116 patients suffering from type 2 diabetes mellitus treated with insulin at the Diabetes Care Centre in Pinar del Rio (Cuba), were recruited and randomly. The subjects were separated into two groups: Group A $(\mathrm{n}=59)$, who were administered Diamel and Group B $(n=57)$ using placebo. The clinical and biochemical variables were assessed for 24 weeks. Results: Two subjects were excluded from the Diamel treatment group during the clinical trial. From the statistical point of view, a significant drop in the levels of the baseline glucose, postprandial glucose, glycated haemoglobin, and triglycerides was observed in the group taking Diamel (Group A). There was observed an increase in insulin requirements and in waist circumference in the subjects of Group B. There was not reported any severe or serious adverse reactions during this clinical trial. Conclusion: Diamel (nutritional supplement) together with the administration of insulin in type 2 diabetic patients is useful to optimize the biochemical variables (baseline and postprandial glucose, $\mathrm{Hb}$ $\mathrm{A}_{1 \mathrm{C}}$, plus triglycerides), as well as to prevent the increase of insulin requirements at medium-term.
\end{abstract}

Keywords: Diamel; Dietary Supplement; Type 2 Diabetes; Clinical Trial; Double-Blind

\section{Introduction}

Almost $85 \%$ to $95 \%$ of whole diabetic population suffers from type 2 Diabetes Mellitus [1]. The interaction between genetic and environmental risk factors contributes to the development of this type of diabetes, as they can affect $\beta$-cell function and the peripheral insulin sensitivity [2-4]. New scientific advances state that pathophysiological changes of type 2 diabetes, in which oxidative stress has a major role, can now be treated $[5,6]$. The

\footnotetext{
"This trial was registered with ClinicalTrials.gov (NCT00994266).

The clinical trial was registered at ClinicalTrials.gov (NCT00994266).

I declare that there is not conflict of interest.

${ }^{\#}$ Corresponding author.
}

increase in free radicals inhibits the insulin action and contributes to the deterioration in $\beta$-cell function, leading to chronic complications [7-11]. Several authors have carried out studies on natural products having hopeful results [12-14]. The food supplement Diamel ${ }^{\circledR}$, from Catalysis, S. L. laboratories, is a natural product composed of trace elements: amino acids, vitamins, cranberry extract, and lettuce extract that have been activated by means of a magnetization process which enhances the biological properties of each of every component. Diamel works out on pancreas whereby its components-zinc, arginine and ornithine-help to stimulate the secretion of insulin, while the lettuce extract helps to reduce the gastrointes- 
tinal glucose absorption [15]. Cranberry extract is an effective antioxidant, a hypoglycemic and lipid-lowering agent, which improves $\beta$-cell function by reducing the harmful effects of free radicals $[16,17]$. Our clinical trial was carried out in order to assess how effective Diamel is on the main biochemical metabolic control variables (fasting blood glucose, postprandial glucose, cholesterol, triglycerides, glycosylated hemoglobin $\mathrm{Hb} \mathrm{A}_{1 \mathrm{C}}$ ) in type 2 diabetic subjects undergoing insulin treatment.

\section{Material and Methods}

\subsection{Design}

Randomized in two parallel groups, double-blind, controlled clinical trial. A central randomization centre used computer generated tables to allocate treatments.

\subsection{Participants}

116 patients were recruited and randomized. They were diagnosed as type 2 diabetes mellitus and were given a double dosage of intermediate-acting insulin. The patients were taking medical care in an out-patient unit and control at the Diabetic Care Centre in Pinar del Río province.

\subsection{Eligibility}

Patients included in the clinical trial met the following inclusion criteria: both genders, ages from 40 to 65 , those suffering from type 2 diabetes for 0 - 15 years, calculated when they were first diagnosed, and those receiving the written informed consent to take part in the clinical trial. Those patients meeting the inclusion criteria but refusing to take part in the study or those who showed moderate to severe chronic complications, sepsis or having intercurrent diseases that could interfere with the clinical trial, some way, were excluded.

\subsection{Settings}

The study took place at the Diabetic Care Center and at "Abel Santamaría Cuadrado" University Hospital, in Pinar del Río province, Cuba, from October 2009 to April 2011.

\subsection{Interventions}

The subjects were given a double dosage of intermediate-acting insulin, they were randomly separated into two groups: Group A $(\mathrm{n}=59)$, who were administered Diamel (two capsules of $660 \mathrm{mg}$ before breakfast, lunch and dinner), and Group B $(n=57)$ using placebo in the same dosage (Control group). A central randomization centre used computer generated tables to allocate treatments the clinical and biochemical variables (baseline and postprandial glucose; $\mathrm{Hb} \mathrm{A}_{1 \mathrm{C}}$, cholesterol, and triglycerides) were assessed during six months in both groups. All the patients' variables were assessed in baseline conditions; their biochemical and anthropometric values were determined. The patients received pieces of advice and counselling from dieticians and were asked to practice gentle and gradual physical activity (walk for 30 to 45 minutes), 3 or 4 times a week.

The components of Diamel are shown in the Table 1.

\subsection{Outcomes}

Primary Outcome Measures:

1) Difference in daily dosage of insulin at 24 weeks and the beginning of the study;

2) Difference in the levels of glycemia (fasting and postprandial) at 24 weeks and at the beginning of the study in adjusted doses;

3) Difference in the levels of HbAlc at 24 weeks and at the beginning of the study;

Secondary Outcome Measures:

1) Presence or not of hypoglycemic reactions levels or of major intensity during the 24 weeks of treatment.

\subsection{Sample Size}

The study was designed to a statistical power of $90 \%$, to detect an absolute difference of $30 \%$ in proportions to reduce or maintain insulin requirements together with the improvement of blood glucose levels (50\% in the Diamel group compared to $20 \%$ of the control group) bearing in mind a type 1 error of 0.05 and a type 2 error of 0.10 ; needing 116 patients to reach the statistical significance. A level of $5 \%$ for the statistical significance was considered to carry out the full analysis. The statistical analysis was preformed using SPSS Inc to Windows, version 15, Chicago IL.

Table 1. Components of Diamel.

\begin{tabular}{|c|c|c|}
\hline \multicolumn{3}{|c|}{ Components of Diamel } \\
\hline Arginine $35.5 \mathrm{mg}$ & Glycine 7.1 & $\mathrm{mg}$ \\
\hline Ascorbic acid $10 \mathrm{mg}$ & Ornithine 17.7 & $\mathrm{mg}$ \\
\hline Zinc sulphate $6 \mathrm{mg}$ & $\begin{array}{c}\text { Calcium } \\
\text { pantothenate }\end{array}$ & $1 \mathrm{mg}$ \\
\hline Folic acid $33 \mu \mathrm{g}$ & Cranberry 345 & $\mathrm{mg}$ \\
\hline Fumaric acid $35.5 \mathrm{mg}$ & Lettuce 152 Extract & $\mathrm{mg}$ \\
\hline L-carnitine $35.5 \mathrm{mg}$ & L-Cysteine 14.2 & $\mathrm{mg}$ \\
\hline $\begin{array}{l}\text { Sodium } 0.33 \mathrm{mg} \\
\text { Methylparaben }\end{array}$ & Pyridoxal 0.33 & $\mathrm{mg}$ \\
\hline
\end{tabular}

This product is marketed as a food supplement by the Catalysis Laboratories. (Macarena, 14, 28016 Madrid, Spain). Website: www.diamel.com 


\subsection{Randomisation}

For allocation of the participants, a computer-generated list of random numbers was used (ASAL system). Participants were randomly assigned following simple randomization procedures. Two treatment groups were conformed: an experimental group, with Diamel (Group A), and another control group with placebo (Group B). To each patient was assigned a treatment outline according to the aleatory list. The center was a group of sealed envelopes, one for each patient, with consecutively numbers containing the assignment of treatment. In each envelope a number was included and it was taken as the number of inclusion in the trial.

The randomization was carried out by the members of staff, who were not involved in administering the product or evaluating the patients. Determination of whether a patient was given a double dosage of intermediate-acting insulin or would be treated with Diamel or placebo was made by reference to a statistical series based on random sampling numbers. The details of the series were unknown by any of the investigators or by the co-ordinator. The assignment was carried out at blind by the investigators after the patient gathered the inclusion approaches and they granted the consent to participate in the study. The patient, investigators, data collectors or data analysts had not access to the randomization schedule.

The Diamel and placebo were in capsule form and identical in appearance, taste and smell. Both products (Diamel and placebo) were supplied by Catalysis, S. L. (Madrid, Spain). They were prepacked in bottles and consecutively numbered for each patient according to the randomization schedule. Each patient was assigned an order number and received the capsules in the corresponding prepacked bottle. The method of administration of both products was similar.

\subsection{Statistical Methods}

The baseline characteristics were summarised using absolute frequencies and percentages for the qualitative variables; average and standard deviation were used to summarise the information about quantitative variables. Chi-square test was used to assess the qualitative variable differences between the two groups; and the MannWhitney U-test was used to analyse the quantitative variables.

The Wilcoxon signed-rank test for paired samples was used to examine changes between the start and the end of treatment when assessing the primary and secondary efficacy variables. The differences between the groups were examined using Mann-Whitney U-test.

All significance tests and resulting p-values were twosided, with an alpha level of 0.05 .

\subsection{Ethics}

The clinical trial was carried out in accordance with the ethical principles established in the Declaration of Helsinki. It was also approved by the Ethics Research Committee and the Scientific Board at "Abel Santamaría Cuadrado" University Hospital, Pinar del Río. All patients included signed the consent form to take part in the research programme.

\section{Results}

For each group, the numbers of participants who were randomly assigned, received intended treatment, and were analysed for the primary outcome. The analysis was made according to the aleatory list. The flow chart of the participants (Figure 1) shows what occurred in both groups. Two subjects were excluded from the Diamel treatment group during the clinical trial: one patient got

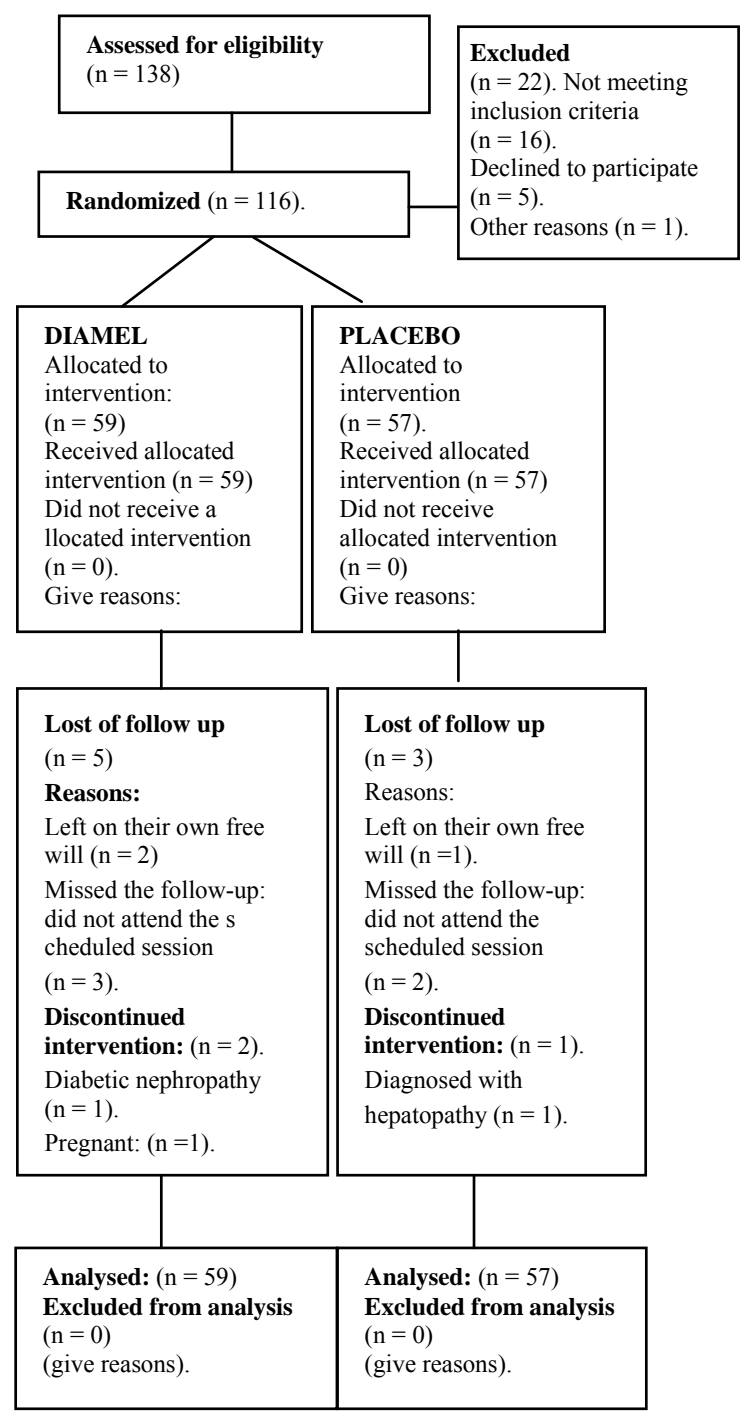

Figure 1. Participant flow chart. 
pregnant in the third month of treatment and the other was identified as being a carrier of diabetic nephropathy during the follow-up. In the control Group B (placebo) one patient was excluded from the clinical trial after being diagnosed with incipient, chronic hepatopathy. Ageeligible participants were recruited from November 2009 to April 2010. All the patients' variables were assessed in baseline conditions; their biochemical and anthropometric values were determined.

Table 2 contains the main biochemical and clinical variables in Group A (Diamel) and Group B (placebo) at the start of the clinical trial. No significant statistical differences were found between the two groups, which indicated that both groups were considered to be similar.

Table 3 shows the comparative analysis of the metabolic control variables after six months of treatment. A significant improvement $(p<0.01)$ was observed in patients of the group treated with Diamel due to lower parameters of: glycosylated hemoglobin (HbAlc), fasting glucose, postprandial glucose, and triglycerides. There were not changes in serum cholesterol levels or the daily insulin requirements. In the group treated with the placebo, a long term increase in cholesterol levels and the insulin requirements was observed. The differences between the group treated with Diamel and the group treated with placebo at the end of the clinical trial, shown in aforesaid table, were noteworthy for almost all the variables assessed.

Table 4 shows the trends of fasting glucose and postprandial glucose variables of both groups at different times in the follow-up (4, 12 and 24 weeks). The lowest average values for these variables were observed at the 24 week of treatment in the group taking Diamel. There was a considerable drop in the levels of glycated haemoglobin (HbAlc) and triglycerides in members of this group compared to the values obtained in the group treated with placebo. Moreover, there was observed an increase in insulin requirements $(0.1 \mathrm{U} / \mathrm{Kg})$ by the 24 th week of follow-up among the subjects of Group B (placebo) and significant differences between the two groups for almost all the variables analysed in the clinical trial. Regarding the anthropometric indicators the waist circumference and the waist-to-hip ratio had decreased by the 12th week of follow-up in the group treated with Diamel. This decrease became even more noticeable by the 24th week. Weight gain was greater and an increase in the abdominal circumference (waist circumference) was observed in members of the group treated with placebo by the end of treatment.

All the results obtained for patients who had been randomly assigned and treated with at least one dose of the product were included in the evaluation (intention to treat analysis). Safety assessment included all patients having at least one safety analysis after the trial starting.
None of the subjects were reported to have any severe or serious adverse reactions during this clinical trial. There were no deaths reported either. Eleven [11] mild hypoglycaemia episodes were reported, although nobody was forced to leave the clinical trial due to this cause.

In our study, cHDL determinations were not carried out, which constitutes a limiting factor of the trial as for the lipids study.

\section{Discussion}

Early metabolic control has beneficial effects on diabetes type 2 . It has been proved that intensive multifactorial treatment reduces the risks of both the microangiopathic and macroangiopathic complications associated with diabetes [4,18-20]. However, the existence of the socalled "metabolic memory" suggests that the early treatment of the different risk factors might be advisable [21].

The emergence of new kinds of therapy over the last 15 or 20 years has greatly improved pharmacological treatment in out-patients with chronic type 2 diabetes. Nevertheless, there are two main reasons why, in certain cases, all hopes have been dashed: real benefits are less than what is expected and/or the safety profile is unsatisfactory [22,23]. That is why modern treatment with natural products has gradually become more valuable and the corresponding evidence has shown that it is indeed effective and safe $[15,24,25]$. This type of product allows care providers to treat the pathophysiological changes associated with the complications of diabetes by reducing the oxidative stress and the formation of advanced glycation end-products (AGE) along with concomitant normalization of glucose, which implies that it is a more effective therapeutic approach [26].

As the groups under analysis in this clinical trial had similar characteristics (clinical and biochemical), the variables could be compared and the possible effects of the natural product used on these subjects could be evaluated. It is the first controlled clinical trial using placebo with similar organoleptic characteristics as Diamel administered to subjects with type 2 diabetes that were also being treated with insulin.

The clinical significance of the Diamel use associated to the therapy with insulin is its positive effect on the biochemical metabolic control variables (baseline blood glucose, postprandial glucose, HbA1c, and triglycerides), and their help to stop the increasing insulin requirements at medium term after 24 weeks of treatment. Another aspect to consider is a reduction in waist circumference. Dan Cheta \& cols [15] obtained similar results after 12 weeks of follow-up in a group of 52 subjects with diabetes type 2 that were given the same treatment, although these authors did not take into consideration the postprandial glucose. Hernández-Yero [25], in a study carried out on 60 subjects using Glibenclamide, obtained similar 
Table 2. Clinical and biochemical variables at the start of the study.

\begin{tabular}{|c|c|c|c|c|c|}
\hline \multirow{2}{*}{$\begin{array}{c}\text { Variables } \\
\text { Age (years), average, standard deviation }\end{array}$} & \multicolumn{2}{|c|}{$\begin{array}{c}\text { Diamel }(n=59) \\
\text { Mean SD }\end{array}$} & \multicolumn{2}{|c|}{$\begin{array}{c}\text { Placebo }(n=57) \\
\text { Mean SD }\end{array}$} & \multirow{2}{*}{$\begin{array}{c}\mathbf{p} \\
0.26\end{array}$} \\
\hline & 56.0 & \pm 7.3 & 54.0 & \pm 8.1 & \\
\hline Male gender, n (\%) & 19 & \pm 2.2 & 26 & \pm 5.6 & 0.20 \\
\hline BMI, average, standard deviation & 28.4 & \pm 5.9 & 28.6 & \pm 4.6 & 0.94 \\
\hline Waist-hip ratio, average, standard deviation & 0.9 & \pm 0.1 & 0.9 & \pm 0.1 & 0.74 \\
\hline Age when diagnosed (years), average, standard deviation & 47.2 & \pm 6.6 & 45.4 & \pm 8.0 & 0.24 \\
\hline Progression of the disease (years), average, standard deviation & 8.4 & \pm 4.5 & 8.0 & \pm 4.3 & 0.32 \\
\hline Diet (calories), average, standard deviation & 1268.4 & \pm 127.0 & 1294.8 & \pm 171.6 & 0.50 \\
\hline Systolic blood pressure ( $\mathrm{mmHg})$, average, standard deviation & 128.4 & \pm 18.5 & 123.1 & \pm 15.9 & 0.12 \\
\hline Fasting glucose (mmol/l), average, standard deviation & 8.3 & \pm 3.3 & 8.2 & \pm 3.1 & 0.93 \\
\hline Postprandial glucose 2 hours (pool/l), average, standard deviation & 11.6 & \pm 3.8 & 10.6 & \pm 3.3 & 0.09 \\
\hline Glycated haemoglobin (\%), average, standard deviation & 12.0 & \pm 4.3 & 11.4 & \pm 3.5 & 0.39 \\
\hline Cholesterol (mmol/L), average, standard deviation & 5.4 & \pm 1.2 & 5.4 & \pm 1.2 & 0.96 \\
\hline Triglycerides (mmol/L), average, standard deviation & 2.7 & \pm 1.8 & 3.0 & \pm 2.4 & 0.82 \\
\hline Insulin requirements $(\mathrm{U} / \mathrm{kg} /$ day), average, standard deviation & 0.5 & \pm 0.2 & 0.6 & \pm 0.2 & 0.12 \\
\hline
\end{tabular}

SD: standard deviation, $\mathrm{p}<0.05$.

Table 3. Evaluation of the effectiveness on the groups before and after the treatment.

\begin{tabular}{|c|c|c|c|c|c|c|c|c|c|c|c|}
\hline \multirow[b]{3}{*}{$\begin{array}{c}\text { Glycated haemoglobin }(\%) \text {, average, standard } \\
\text { deviation }\end{array}$} & \multicolumn{5}{|c|}{ Diamel $(n=59)$} & \multicolumn{5}{|c|}{ Placebo $(n=57)$} & \multirow{3}{*}{$\begin{array}{c}\text { P difference } \\
\text { between the } \\
\text { groups at } \\
\text { the end }\end{array}$} \\
\hline & \multicolumn{2}{|c|}{$\begin{array}{l}\text { Before Mean } \\
\text { SD }\end{array}$} & \multicolumn{2}{|c|}{$\begin{array}{c}\text { After } \\
\text { Mean SD }\end{array}$} & \multirow{2}{*}{$\begin{array}{c}\mathbf{p} \\
<0.01\end{array}$} & \multicolumn{2}{|c|}{$\begin{array}{l}\text { Before Mean } \\
\text { SD }\end{array}$} & \multicolumn{2}{|c|}{$\begin{array}{l}\text { After Mean } \\
\text { SD }\end{array}$} & \multirow{2}{*}{$\begin{array}{c}\mathbf{p} \\
0.30\end{array}$} & \\
\hline & 12.0 & \pm 4.3 & 8.1 & \pm 1.9 & & 11.4 & \pm 3.5 & 10.8 & \pm 3.4 & & \\
\hline $\begin{array}{c}\text { Fasting glucose (mmol/l), average, standard } \\
\text { deviation }\end{array}$ & 8.3 & \pm 3.3 & 7.0 & \pm 2.2 & $<0.01$ & 8.2 & \pm 3.1 & 8.7 & \pm 2.8 & 0.13 & $<0.01$ \\
\hline $\begin{array}{l}\text { Postprandial glucose } 2 \text { hours (pool/1), } \\
\text { average, standard deviation }\end{array}$ & 11.6 & \pm 3.8 & 9.1 & \pm 2.0 & $<0.01$ & 10.6 & \pm 3.3 & 11.6 & \pm 3.5 & 0.06 & $<0.01$ \\
\hline $\begin{array}{c}\text { Triglycerides (mmol/L), average, standard } \\
\text { deviation }\end{array}$ & 2.7 & \pm 3.3 & 1.8 & \pm 1.4 & $<0.01$ & 3.0 & \pm 2.4 & 2.8 & \pm 1.8 & 0.21 & $<0.01$ \\
\hline $\begin{array}{c}\text { Cholesterol }(\mathrm{mmol} / \mathrm{L}), \text { average, standard } \\
\text { deviation }\end{array}$ & 5.4 & \pm 1.2 & 5.4 & \pm 1.2 & 0.68 & 5.4 & \pm 1.2 & 5.8 & \pm 1.1 & 0.01 & 0.02 \\
\hline $\begin{array}{c}\text { Insulin requirements }(\mathrm{U} / \mathrm{kg} / \text { day }), \text { average, } \\
\text { standard deviation }\end{array}$ & 0.5 & \pm 0.2 & 0.5 & \pm 0.2 & 0.40 & 0.6 & \pm 0.2 & 0,7 & \pm 0.3 & $<0.01$ & $<0.01$ \\
\hline
\end{tabular}

$\mathrm{SD}$ : standard deviation, $\mathrm{p}<0.05$.

results in terms of reducing the levels of fasting glucose, postprandial glucose, HbAlc and another interesting result found in our own clinical trial was the significant increase $(p<0.01)$ in insulin requirements of members of the control group treated with placebo by the end of the study.

These positive effects on the biochemical variables are probably due to the activated components in Diamel, which include zinc (a biocatalyst). A zinc deficiency is thought to reduce the secretion of insulin and reduce tissue resistance to this hormone's action, which in turn, leads to an increase in the circulating glucose levels [27]. Other ingredients such as the arginine (essential amino acid), its precursor (ornithine), and the antioxidants (cranberry and ascorbic acid) improve the secretion of insulin, favour lipid movement and protect cells from the damaging effects of the free radicals, respectively [25,28]. Moreover, the lettuce extract decreases the amount of 
Table 4. Evaluation of the effectiveness during the treatment.

\begin{tabular}{|c|c|c|c|c|c|c|c|c|c|c|c|c|c|c|c|}
\hline \multirow{2}{*}{ Variables } & \multicolumn{6}{|c|}{ Diamel (n = 59) } & \multicolumn{6}{|c|}{ Placebo $(n=57)$} & \multicolumn{3}{|c|}{$\begin{array}{l}\text { P difference between the } \\
\text { groups at the end }\end{array}$} \\
\hline & \multicolumn{2}{|c|}{$\begin{array}{l}4 \text { weeks } \\
\text { Mean SD }\end{array}$} & \multicolumn{2}{|c|}{$\begin{array}{l}12 \text { weeks } \\
\text { Mean D }\end{array}$} & \multicolumn{2}{|c|}{$\begin{array}{l}24 \text { weeks } \\
\text { Mean SD }\end{array}$} & \multicolumn{2}{|c|}{$\begin{array}{l}4 \text { weeks } \\
\text { Mean SD }\end{array}$} & \multicolumn{2}{|c|}{$\begin{array}{l}12 \text { weeks } \\
\text { Mean SD }\end{array}$} & \multicolumn{2}{|c|}{$\begin{array}{c}24 \text { weeks Mean } \\
\text { SD }\end{array}$} & 4 weeks & 12 weeks & 24 weeks \\
\hline $\begin{array}{l}\text { Glycated haemoglobin (\%), } \\
\text { average, standard deviation }\end{array}$ & 10.4 & \pm 3.4 & 9.3 & \pm 2.1 & 8.1 & \pm 1.9 & 11.3 & \pm 3.4 & 11.3 & \pm 3.9 & 10.8 & \pm 3.4 & 0.15 & $<0.01$ & $<0.01$ \\
\hline $\begin{array}{c}\text { Fasting glucose }(\mathrm{mmol} / \mathrm{l}), \\
\text { average, standard } \\
\text { deviation }\end{array}$ & 7.9 & \pm 2.8 & 7.6 & \pm 3.2 & 7.0 & \pm 2.2 & 8.6 & \pm 3.7 & 8.2 & \pm 2.8 & 8.7 & \pm 2.8 & 0.42 & 0.10 & 0.01 \\
\hline $\begin{array}{l}\text { Postprandial glucose } 2 \\
\text { hours (pool/1), average, } \\
\text { standard deviation }\end{array}$ & 10.9 & \pm 3.7 & 9.9 & \pm 3.1 & 9.1 & \pm 2.0 & 10.7 & \pm 3.4 & 10.5 & \pm 3.6 & 11.6 & \pm 3.5 & 0.94 & 0.26 & $<0.01$ \\
\hline $\begin{array}{c}\text { Triglycerides }(\mathrm{mmol} / \mathrm{L}), \\
\text { average, standard } \\
\text { deviation }\end{array}$ & 2.4 & \pm 1.4 & 2.1 & \pm 1.1 & 1.8 & \pm 1.0 & 2.8 & \pm 2.3 & 2.8 & \pm 1.9 & 2.8 & \pm 1.8 & 0.40 & 0.06 & $<0.01$ \\
\hline $\begin{array}{c}\text { Cholesterol }(\mathrm{mmol} / \mathrm{L}), \\
\text { average, standard } \\
\text { deviation }\end{array}$ & 5.0 & \pm 1.1 & 5.0 & \pm 1.0 & 5.4 & \pm 1.1 & 5.4 & \pm 1.4 & 5.5 & \pm 1.2 & 5.8 & \pm 1.1 & 0.13 & 0.02 & 0.02 \\
\hline $\begin{array}{l}\text { Insulin requirements } \\
\text { (U/kg/day), average, } \\
\text { standard deviation }\end{array}$ & 0.6 & \pm 0.2 & 0.6 & \pm 0.2 & 0.5 & \pm 0.2 & 0.6 & \pm 0.2 & 0.7 & \pm 0.2 & 0.7 & \pm 0.3 & 0.13 & 0.02 & $<0.01$ \\
\hline
\end{tabular}

SD: standard deviation, $\mathrm{p}<0.05$.

glucose absorbed by the intestine by $30 \%$ and improves the postprandial glucose levels [29].

The slight rise in cholesterol levels in both groups was statistically insignificant. The triglyceride levels had dropped significantly by the 12th week of this clinical trial and had dropped even more by the 24 week-followup. These beneficial results in the lipid levels seem to be related to the improvement in the blood glucose control. Reducing triglycerides is one of the main objectives of the treatment, as hypertriglyceridemia (regardless of the cholesterol values) is closely associated with cardiovascular disease [30,31]. The evaluation of effectiveness carried out at different times during the treatment highlighted a significant increase in the insulin requirements by the 12th week right up until the end of the clinical trial. It is known that insulin requirements can be increased by the progressive deterioration of the islets of Langerhans [32]. These requirements remained unchanged among the subjects using Diamel until the end of the clinical trial, according to the average values obtained at the beginning and at the end $(0.5 \mathrm{U} / \mathrm{Kg} /$ day $)$. During the follow-up however, this parameter did go up to $0.6 \mathrm{U} / \mathrm{Kg} /$ day between the 4th and the 12th week and then dropped down again to the initial value by the 24th week. This all seems to point out to the fact that although Diamel did not manage the reduction of insulin requirements during the period analysed ( 24 weeks), it could be used to control insulin requirements that tend to increase on a long-term basis, as observed in the subjects that were administered placebo.
With regards to the minor episodes of hypoglycemia observed during the study, when the total dose of insulin was reduced slightly, the symptoms of glycopenia disappeared without producing any statistical changes in the daily insulin requirements. One point to be considered in this case would be the possible influence that the changes in the anthropometric variables might have: a reduction in waist circumference and the waist-hip ratio, which were observed from the 12th week onwards and during the 24 weeks of follow-up in Group A. Contrary to these results, members of the control group given placebo were seen to gain more weight and their waist circumference increased, which might explain the increase in this group of insulin requirements by the end of the clinical trial. Hernández Yero [25] did not obtain any important results from the subjects using oral anti-diabetic medication in this sense. The pieces of advice given to these patients regarding diet and physical activity in both groups, ruled out any possible effects on the parameters these results obtained may have had.

These results could be used as a platform for a further research that will be carried out on subjects with similar characteristics for a longer period of time. It has been published before about the effectiveness of the Diamel on Metabolic Syndrome [24] and the diabetes treated with Glibenclamide [25].

However their effectiveness in type 2 diabetic patients receiving insulin therapy was ignored. This trial also demostrated its effectiveness in type 2 diabetic patients receiving insulin therapy. 


\section{Conclusion}

The option of using the food supplement (Diamel) together with the insulin therapy in people suffering from type 2 diabetes is effective to optimize the biochemical metabolic control variables (baseline blood glucose, postprandial glucose, $\mathrm{HbAlc}$, and triglycerides), and it also seems to help to stop the increasing insulin requirements at medium term. It could be a new alternative of treatment for patients with DM2 being treated with insulin.

\section{Acknowledgements}

This study was carried out under the auspices of Catalysis Laboratory of Madrid, Spain and the participation of the Diabetes Care Center belonging to "Abel Santamaria Cuadrado" University Hospital, Pinar del Rio-Cuba. We feel a deep sense of gratitude toward the patients participating in this trial; and to the Biochemical Department of the above mentioned institution.

\section{REFERENCES}

[1] American Diabetes Association, "Diagnosis and Classification of Diabetes Mellitus," Diabetes Care, Vol. 33, No. S1, 2010, pp. S62-S69. doi:10.2337/de10-S062

[2] B. F. J. Ampudia, "Fallo Celular Beta y Progresión de la Diabetes Mellitus Tipo 2," Endocrinology and Nutrition, Vol. 50, No. 7, 2003, pp. 274-279.

[3] R. González, E. Buchaca and M. Licea, "Fisiopatología y Progresión de las Personas con," Revista Cubana de Endocrinología, Vol. 10, No. 1, 2011, pp. 11-17.

[4] UK Prospective Diabetes Study 16, "Overview of 6 Years Therapy of Type 2 Diabetes: A Progressive Disease. United Kingdom Prospective Diabetes Study Group," Diabetes, Vol. 45, No. 11, 1996, pp. 1249-1258. doi:10.2337/diabetes.44.11.1249

[5] D. M. Nathan, J. B. Buse, M. B. Davidson, E. Ferrannini, R. R. Holman, R. Sherwin, et al., "Medical Management of Hyperglycemia in Type 2 Diabetes: A Consensus Algorithm for the Initiation and Adjustment of Therapy: A Consensus Statement of the American Diabetes Association and the European Association for the Study of Diabetes," Diabetes Care, Vol. 32, No. 1, 2009, pp. 193203. doi: $10.2337 / \mathrm{dc} 08-9025$

[6] R. Bastarrachea, J. Montero, V. Saavedra, R Cerda, A. Machado and A. Comuzzie, "Objetivos Moleculares Para Diseñar Nuevos Fármacos Para el Tratamiento de la Diabetes Tipo 2 y la Obesidad," Revista Médica de Chile, Vol. 136, No. 1, 2008, pp. 107-117. doi:10.4067/S0034-98872008000100014

[7] J. L. Evans, I. P. Goldfine, B. A. Maddus and G. M. Grodsky, "Are Oxidative Stress-Activated Signalling Pathways Mediators of Insulin Resistance and Beta-Cell Dysfunction?" Diabetes, Vol. 52, No. 1, 2003, pp. 1-8. doi:10.2337/diabetes.52.1.1

[8] R. Robertson, J. Harmon, P. Oanh and V. Poitout, "Beta
Cell Glucose Toxicity, Lipotoxicity and Chronic Oxidative Stress in Type 2 Diabetes," Diabetes, Vol. 53, No. 1, 2004, pp. S119-S124. doi:10.2337/diabetes.53.2007.S119

[9] G. Orasanu and J. Plutzky, "The Pathologic Continuum of Diabetes Vascular Disease," Journal of the American College of Cardiology, Vol. 53, No. 5, 2009, pp. S35-S42. doi:10.1016/j.jacc.2008.09.055

[10] Y. Yu and T. J. Lyons, "A Lethal Tread in Diabetes, Hyperglucemia, Dyslipemia, Oxidative Stress and Endothelial Dysfunction," American Journal of Medical Science, Vol. 330, No. 5, 2005, pp. 227-232. doi:10.1097/00000441-200511000-00005

[11] J. M. Forbes, M. T. Coughlan and M. E. Cooper, "Oxidative Stress as a Major Culprit in Kidney Disease in Diabetes," Diabetes, Vol. 57, No. 6, 2008, pp. 1446-1454. doi: 10.2337/db08-0057

[12] W. Jia, W. Gao and L. Tang, "Antidiabetic Herbal Drugs Officially Approved in China," Phytotherapy Research, Vol. 17, No. 10, 2003, pp. 1127-1134. doi: $10.1002 /$ ptr. 1398

[13] B. Ludvik, B. Neuffer and G. Pacini, "Efficacy of Ipomea Batatas (Caiapo) Ondiabetes Control in Type 2 Diabetes Subjects Treated with Diet," Diabetes Care, Vol. 27, No. 2, 2004, pp. 436-440. doi:10.2337/diacare.27.2.436

[14] E. A. Sotoniemi, E. Haapakoski and A. Rautio, "Ginseng Therapy in Non-Insulindependent Diabetic Patients. Effect on Psychophysical Performance, Glucose Homeostasis, Serum Lipids, Serum Aminoterminal-Propeptide Concentration and Body Weight," Diabetes Care, Vol. 18, No. 10, 1995, pp. 1373-1375.

[15] D. Cheta and F. Trifan, "Diamel Associated with Insulin or ADO or as a Pharmacological Monotherapy," 2010. http://www.catalysisusa.net/stud_Diamel.html

[16] P. E. Milbury, B. Graf and J. M. C. Celentano, "Bilberry (Vaccinium myrtillus) Anthocyanins Modulate Heme Oxygenase-1 and Glutathione S-Transferasepi Expression in ARPE-19 Cells," Investigative Ophthalmology and Visual Science, Vol. 48, No. 5, 2007, pp. 2343-2349. doi:10.1167/iovs.06-0452

[17] C. Olvera, G. Leo and H. Hernández, "Páncreas y Células Beta: Mecanismos de Diferenciación, Morfogénesis y Especificación Celular Endocrina. Regeneración?" Boletín Médico del Hospital Infantil de México, Vol. 65, No. 4, 2008, pp. 306-324.

[18] Writing Team for the Diabetes Control and Complications Trial/Epidemiology of Diabetes Interventions and Complications Research Group, "Sustained Effect of Intensive Treatment of Type 1 Diabetes Mellitus on Development and Progression of Diabetic Nephropathy: The Epidemiology of Diabetes Interventions and Complications (EDIC) Study," The Journal of American Medical Association, Vol. 290, No. 16, 2003, pp. 2159-2167. doi:10.1001/jama.290.16.2159

[19] D. M. Nathan, P. A. Cleary, J. Y. Backlund, S. M. Genuth, J. M. Lachin, T. J. Orchard, et al., "Diabetes Control and Complications Trial/Epidemiology of Diabetes Interventions and Complications (DCCT/EDIC) Study Research Group. Intensive Diabetes Treatment and Cardio- 
vascular Disease in Patients with Type 1 Diabetes," New England Journal of Medicine, Vol. 353, No. 25, 2005, pp. 2643-2653. doi:10.1056/NEJMoa052187

[20] S. Colagiuri, C. A. Cull and R. R. Holman, "Are Lower Fasting Plasma Glucose Levels at Diagnosis of Type 2 Diabetes Associated with Improved Outcomes? UK Prospective Diabetes Study 61," Diabetes Care, Vol. 25, No. 8, 2002, pp. 1410-1417. doi: $10.2337 /$ diacare.25.8.1410

[21] A. Ceriello, "La 'Memoria Metabólica' Inducida por la Hiperglucemia: El Nuevo Reto en la Prevención de la Enfermedad Cardiovascular en la Diabetes," Revista Española de Cardiología, Vol. 8, No. SC, 2008, pp. 1218.

[22] J. A. Arguedas, "Effectividad y Seguridad Comparativa de los Medicamentos Para la Diabetes Tipo 2: Una Actualización Incluyendo Nuevas Drogas y Combinaciones de dos Drogas. Actualización Médica Periódica," 2011. www.ampmd.com

[23] W. L. Bennett, N. M. Maruthur and S. Singh, "Comparative Effectiveness and Safety of Medications for Type 2 Diabetes: An Update Including New Drugs and 2-Drug Combinations," Annals of Internal Medicine, Vol. 154, No. 9, 2011, pp. 602-613.

[24] R. Cabrera, "Diamel Intervention Trial on Metabolic Syndrome. AcciMonitor," 2010. http://www.finlay.sld.cu/publicaciones/vaccimonitor/Vm 2010/Abstracts-Pharmacology-2010.pdf

[25] A. H. Yero and D. Vargas "Utilidad de Diamel en Pa- cientes con Diabetes Mellitus Tipo 2 en Tratamiento Combinado con Glibenclamida," Avances en Diabetología, Vol. 23, No. 1, 2007, pp. 284-290.

[26] S. S. Sheu, D. Nauduri and M. W. Anders, "Targeting Antioxidants to Mitochondria: A New Therapeutic Direction," Biochimica et Biophysica Acta, Vol. 1762, No. 2, 2006, pp. 256-265. doi:10.1016/j.bbadis.2005.10.007

[27] A. Gómez, E. Hernández, M. González and E. Martínez, "Efecto de la Administración Oral de Zinc Sobre Sensibilidad a la Insulina y Niveles Séricos de Leptina y Andrógenos en Hombres con Obesidad," Revista Médica de Chile, Vol. 134, No. 3, 2006, pp. 279-284.

[28] F. M. Vaz and R. Wanders, "Carnitine Biosynthesis in Mammals," 2002. http://www.biochemj.org/bj/361/0417/3610417.pdf

[29] E. Trifan and D. Cheta, "Study on Use of Diamel in the Treatment of Diabetes Mellitus," Nutritie si Boli Metabolic, Vol. 1, No. 1, 2002, pp. 23-38.

[30] E. Shafrir and I. Raz, "Diabetes: Mellitus or Lipidus?" Diabetologia, Vol. 46, No. 3, 2003, pp. 433-440.

[31] R. A. DeFronzo, "Insulin Resistance, Lipotoxicity, Type 2 Diabetes and Atherosclerosis: The Missing Links. The Claude Bernard Lecture 2009," Diabetologia, Vol. 53, No. 7, 2010, pp. 1270-1287. doi:10.1007/s00125-010-1684-1

[32] R. Hernando, "Etiología y Fisiopatología de la Diabetes Mellitus Tipo 2," Revista México de Cardiology, Vol. 22, No. 1, 2011, 5 p. www.medigraphic.com/revmexcardio 